\title{
Islamic Religious Literacy Practice And Ideology: A Case Study On Two Religious Student Organizations of Public University In Lombok Island
}

\author{
Agus Iswanto ${ }^{1}$, Joko Tri Haryanto ${ }^{2}$, Ahmad Muntakhib ${ }^{3}$ \\ ${ }^{1,2,3}$ Religious Research, Development and Training Agency, Ministry of Religious Affairs, Jakarta, Indonesia \\ agus.iswanto83@gmail.com ${ }^{1}$,jejakagama@yahoo.co.id ${ }^{2}$, amuntakhib88@gmail.com ${ }^{3}$
}

\begin{abstract}
Religious literacy is related to a certain ideological motif that directs the literacy practice. The study would like to present the relationship between the practice of religious literacy and the ideology in public university by means of case study in the City of Mataram, Lombok island, West Nusa Tenggara. The study will be conducted based on a case study in two Islamic-based organizations (A and B group) of a public university in that city. The study defines that group A has been committing the culture of listening more in religious literacy and thus the literacy of the group is a passive one, while group B is active literacy, because it has been committing not only the culture of listening but also the culture of interpreting, indicated by academic writing programs on the Qur'an. These literacies might be traced back to the ideological base and patron that both groups have adopted.
\end{abstract}

Keywords

Religious literacy, ideology, Islamic student organization, public university

Article Received: 10 August 2020, Revised: 25 October 2020, Accepted: 18 November 2020

\section{Introduction}

An opinion in one of the Indonesian national newspapers has questioned the importance of developing religious literacy in order to improve the more tolerant, contextual and peaceful understanding of religion [1]. Such view is actually good but it might trigger some sort of problem simplification: by means of religious literacy all kinds of religion-related problems will be solved and the life of religion will be peaceful due to the presence of the religious literacy. Unfortunately, a more critical perspective to a practice of literacy, including the religious literacy itself, is related to certain ideological motives that govern the practice of literacy [2]. Therefore, it might be stated that what has been read and what has been written and also how the reading and the writing has been conceived by an individual or a group of certain individuals are related to the ideological motives that the individual or the group of certain individuals have internalized.

That relationship is revealed by Brandt [3]. He shows that reading Bible obediently has become the activity of Sunday School in the $19^{\text {th }}$ Century. Then, the dichotomy between reading and writing has occurred ever since then. The dichotomy has occurred because reading and writing construct the paradigm in different manner. Reading is considered as an activity of internalizing the religious values through the reading of God's revelation, while writing is considered as an activity of reconstructing the mind; as a result, writing is considered as a profane activity in comparison to reading. Furthermore, reading is considered as a more sacred activity because it is identical with obedience. Not to mention, writing tends to be performed in the context outside the church such as trade, office and politics. "The secularization" between reading and writing thus marks the literacy activity that the churches sponsor and that is finally engaged in mass reproduction through the learning process in the schools. In brief, reading is believed to be the sign of obedience while writing is believed to be the sign of criticality.

As the general practice of literacy that relates to the practice of education [4]-[6], the practice of religious literacy also relates to the practice of religious education and the practice of religious education is not apart of ideology. This relationship is found in a study by Saparudin who has analysed the relationship between ideology and practice of education in several Islamic educational institutions [7], [8]. Long before that, actually Ahmad Shalaby, as having been quoted 
by Saparudin, has suspected the presence of ideological-theological motivation in the establishment of the first Islamic boarding school namely Nizamiyah [7]. According to Shalaby, the Islamic boarding school has been established in order to socialize the ideology of Sunni as an effort of preventing the influence and the dissemination of the ideology of Syiah. Similar argument has also been proposed by Safi [9], who shows the relationship between the ideology of the ruler and the production of Islamic knowledge that occurred in the Dynasty of Saljuk.

A study of literacy practice in other religion, which is more recent, is conducted by Rackley; he investigates the practice of religious literacy in two different Christian communities [10]. Although he uses the term "culture" to show the different practice of religious literacy in the two different Christian communities among the young American generation, the intention of the practice is to establish a worldview or a faith that distinguishes the practice of both Christian communities. The first group, known as Methodist, practises a literacy that has been more influenced by the "culture of interpretation" of Bible because the members of the group have actively established the meaning of their religion literacy through discussions and interpretations. On the other hand, the second group, known as Latter-Day Saint, practises the religion literacy by means of "culture of listening" of Bible because the members of the group passively and literally accept the meaning of their literacy from what has been written in the Bible. Therefore, the practice of religious literacy that takes place between both groups consists of the activities of reading and memorizing, which are considered to be more related to the faithfulness and the obedience. Based on the results of his study, it might be argued that the practice of religious literacy the first group has committed is more criticalsubstantial while the practice of religious literacy the second group has committed is more formalist-doctrinaire. Thus, it might be concluded that the literacy practice always involves the aspects of ideology or faithfulness that has been internalized within an individual or a group of individuals who practices the religion.
However, a study that explores the relationship between the religious literacy and the ideology, especially in the Indonesian context, has not been conducted intensively whereas such study is important to conduct so that the patterns of religious literacy practice along with their motives might be identify. Throughout the study, the gap in this topic will be pursued and the results of the investigation toward the relationship between the religious literacy practice and ideology in the public university will be displayed.

Investigating religious literacy practice in the public university is important and interesting to conduct. The reason is that universities become the place where the discourse of religion and faithfulness is discussed and influences the discourse of religion in the surrounding community. Public universities are the place where many people from different faith, religion, social background, culture and political views meet and learn from each other. Although these people (who belong to the same universities) occupy a local area within the universities or regions, they are connected with the national and global problems including the ones related to religion and nation [11].

The religious literacy practice that will be discussed in the study is the one that has been performed around the community of Muslim university students or Muslim student organization. In other words, it might be stated that the religious literacy practice that will be discussed in the study is the practice of Islam literacy. The practice of Islam literacy has been selected because this practice seems to be more prominent in comparison to the practice of other religion literacy. Despite the reason, the practice of Islam literacy might be a role model on how the practice of religious literacy might have relationship with the ideology for every community that performs the religious literacy practice.

The activities of Islamic preach and education in public universities are often seen as the activities of a community known as Islamic Campus 
Preaching Institution (LDK, Lembaga Dakwah Kampus) or any other institutions that bear the similar concept. Usually, the studies toward such institutions are related to the activities that have been performed, the books, the literatures that have been read or the affiliation to the transnational Islamic ideology or thought and the potential radicalism within these institutions. These studies have not sought to appreciate the presence of other groups that actually operate within the activities of Islamic preach, or specific to the study, within the activities of Islam literacy. In the same time, these studies have not sought to appreciate the similarities and the differences among the existing groups. Not to mention, these studies have not targeted the other Indonesian regions since most of them are focused on Java, which is the basis of several well-known universities in Indonesia [12]-[17]. On the contrary, these studies toward the other Indonesian regions, such as the Province of West Nusa Tenggara, have not been clearly mapped. Therefore, the study will serve as another means for viewing the activities of Islamic preach through the perspective of literacy practice in two different communities under the same university.

\section{Theoretical Frameworks}

Literacy practice refers to a set of literacy events that occurs repetitively or that occurs under certain pattern. A study of ideology toward the literacy practice in general is divided into two contrary models of literacy namely the "autonomy model" and the "ideology model." The autonomy model is frequently used in referring to the "literacy thesis" that has been proposed by Jack Goody as having been quoted by Dewayani and Retnaningdyah [2], namely that literacy is considered as an independent variable that influences the cognitive and social capacity of an individual. On the contrary, the autonomy model views reading and writing as a neutral and context-free process which main objective is to achieve the state of "literacy" within a community. The state of literacy encourages the importance to teach literacy in a community as part of the skills for arranging and discerning texts. The autonomy model is frequently proposed in the domains of education and psychology, which tend to view literacy as a cognitive process. In the same time, the autonomy model also teaches certain mechanistic strategies so that students will understand texts and write their opinions articulatively [2].

This model, that tends to neglect the subjectivity of an individual, later is criticized because it is consider to obscure the ideological and the social factors that form the practice of literacy. A study by Brian Street about the practice of literacy in Iran on 1970s, which was conducted anthropologically, has found three kinds of the practice of literacy: literacy of learning place in Qur'ani schools, literacy of secularism in formal schools and literacy of commerce among the fruit traders. In his study, Street has concluded that the process of reading and writing (education in the wide sense) occurs in the context of power relationship that puts human beings on the different positions within the society. This model is called as ideology model, which then will be more prominent due to its view that has been developing within the society [18].

Based on the above explanation, the present study then will rely on the ideology model as the theoretical framework that will be used for viewing the practice of literacy in two religion communities. With this model, the literacy will not only be comprehended as a set of mechanistic skills in relation to reading and writing but also as a social practice that accommodates the values, the cultural experiences and the ideological interest that people believe to influence the interaction between an individual and a text. The ideology model does not neglect the important role of literacy in establishing the cognitive and social transformation of an individual. However, by viewing literacy in a more contextual manner, as having been offered by the ideology model, certain aspect such as power relationship that might encourage or inhibit the process of cognitive transformation within an individual might be disclosed.

Therefore, the present study strives to investigate the relationship that has been established between 
the practice of religion literacy and the ideolog that might influence the practice of literacy. Ideology in the present study is understood in accordance to Street's definition of ideology. Indeed, street does not provide explicit explanation about the meaning of ideology in the literacy model that he has proposed but he implicitly states that the ideology model originates from the conception of knowledge, identity and the presence of the people who practice literacy [18].

Street's point of view is in line with the opinion by Eagleton about ideology. According to Eagleton, ideology is the construction of meaning and values that are juxtaposed with certain interests that are relevant to the social power [19]. Ideology, as having been defined by Charlence Tan [20], refers to the belief that becomes the framework of self-definition and its relationship with the world which directs the life of individuals and groups. This belief includes values, habits, norms and other elements that form ideology. Therefore, ideology might be defined as the values that are believed to be relevant as social power [7].

Religion and ideology are frequently associated to each; as a result, such association leads to the formation of religious ideology. Actually, ideology itself is not a religion and vice versa. However, ideology benefits religious ideas for most of the times and, similarly, political ideas (social power) frequently looks for its origin in the religious ideas [21]. The relationship between ideology and religion starts from a theological belief that develops into a communal association and then becomes institutionalized as ideological social-politic movements. Thereby, religious ideology might be viewed in terms of several elements. First, there is a system of understanding that has been based on religion teachings both in the form of school of thoughts and in the form of the concepts by certain figures. In this stage, religionism has not evolved into ideology. Second, the belief and understanding of certain religions then will be turned in the foundation of justification or legitimation of action both internally and externally. In this stage, there is a shift from mere religious understanding toward ideology that might enable the internalization, the identity formation and the claim of truth. Third, there is a desire to strengthen the existence. In this stage, desire becomes dominant and the dominant desire grows and manifests in multiple strategies and media. Such contemplation has been used in a study by certain experts such as [7], [9], [22], [23].

The relationship between religious ideology and Islamic educational process and institution has been studyed by several scholars. Ahmad Shalaby as having been mentioned by Saparudin suspects the presence of ideological motivation within the educational process in Madrasah Nizamiyah. In the modern times, several studys have been conducted toward the association between religious ideology and education (educational process and institution) such as the studys by scholars [20], [24]-[27].

The elaboration on the association between the ideology and the educational institutions has led to the understanding toward the relationship between ideology and practice of literacy as having been previously explained. The practice of literacy cannot be set apart from the education because the implementation of education itself is originally the practice of literacy itself. Therefore, speaking about Islamic education will not be separated from the discussion on the practice of Islam literacy. Indeed, the practice of Islam literacy as part of the practice of religion literacy has certain characteristics but this fact does not diminish its association to the process of Islamic education that several religious groups or communities have pursued.

The characteristics of Islamic literacy as the practice of religious literacy are as follows. First, the practice of Islam literacy is centred upon the text (the definition of text might be expanded); the text might be the sacred texts as Koran or the religious texts that have been resulted from the religious thoughts or contemplations. Second, the texts that become the focus of the practice of Islam literacy might be used from one generation to another. Third, the sacred religious texts 
become the part of religious rituals. Fourth, the religious texts, both the sacred ones and the profane ones, become the part of individual and collective identity [28]. Therefore, the practice of Islam literacy means the practice of literacy that relates to the primary texts (The Qur'an and Hadith) and the secondary texts of Islamic teachings that become the main reference in the practice of literacy. These texts will be the part of religious rituals and the part of individual and collective identity. In the last part, the association between ideology and education will be apparent.

\section{Research Method}

Through the description on the four characteristics of the practice of Islamic literacy and its association with ideology, a case study will be selected for the conduct of the present study. The case study is selected because the present study conducted in a single place. The location for the present study then is the biggest state university in the province of West Nusa Tenggara. This university is not a religion-based university; instead, it is a public university. The university is located in the centre of the city in the Province of West Nusa Tenggara.

By selecting one of the public universities, the results of the present study are expected to be able to describe how the public universities in the central part of Indonesia hold the practice of religious literacy. Then, the present study will focus on the university-level student groups whose main activities are held in the domain of Islam. The study will involve two groups or two internal Islamic organizations. The two groups are selected because they are structurally under the university (rectorate) supervision. The two organizations are under the supervision of a lecture or a group of lectures who have been assigned to coach the two organizations.

As a guideline in the data gathering activities, the present study would like to refer to the four criteria of religious literacy that have been proposed by Rosowky [28]. The present study benefits multiple data sources in the data gathering process. These data sources consist of documentation, interview and observation. In addition, the present study employs focus group discussion (FGD). FGD performed in the beginning of the study in order to attain preliminary and overall information from the informants or the participants under investigation. Then, interview along with documentation and observation has been conducted. The interview conducted in semi-structured manner toward the informants. However, in certain occasions the unstructured interview has been conducted as well so that the informants will be more convenient in delivering their information.

The interview was conducted in order to attain the data on the religious views of the informants along with the reasons behind the selection of certain religious texts. The interview was conducted to the caretakers of the two organizations and also to the coaches and the students who have joined the two organizations. The interview was supported by the data from the documentation, namely the documentation of religious texts that have been used by the two religious groups. The texts then will be turned into the textual elements for the study. The present study intends to identify the ideology or "the system of faith" that has been hidden within the texts; in other words, the main objectives in conducting the study is to identify the hidden meaning and value which might not be explicit during the preliminary reading. Interview and text (document) study is useful for digging information on how texts can be parts of collective identity and group ideology. The text study in the present study is followed up by an observation toward the activities of the activists from both groups. The observation intends to identify the pattern of activities that have been performed by both groups. Furthermore, the observation will also be useful to see how texts can be manipulated in the sequence of their actions.

\section{Results and Discussion}

\section{Two Islamic Student Organizations}


There are two religious organizaitions. These organizations have different focus in its activities and rituals, but both are intra-organization in that public university. The two intra-university religious organizations are named Lembaga Dakwah Kampus (LDK, Islamic-Preach Institution in University Level) and Pusat Studi Alquran (PSQ, Centre for the Qur'an Study). LDK organization appears first in 1987 and then PSQ organization in 2006.

The emergence of LDK in 1987 was related to the rise of the tarbiyah movement in the 1980s on public campuses in Indonesia. As having been investigated by Rof'ah [29], general characteristics of LDK organization in this campus are similar to the LDK organization in other universities throughout Indonesia. The activities that the LDK Organization in this campus holds are weekly halaqah, mentoring sessions for new students, and recruitment or regeneration. Then, the other activities that the LDK Organization in this university holds are celebration of religious festival days, gathering humanitarian aids for Rohingya and Palestine and gathering aids for the victims of didaster. The interview with the LDK activists shows that there is a synergy of activities between the LDK Organization in the university and numerous companies in Mataram and even throughout the Province of West Nusa Tenggara. The synergy of activities is possible to establish due to the presence of Friendship Forum (FSLDK, Forum Silaturahim Lembaga Dakwah Kampus) in the Province of West Nusa Tenggara. The establishment of the synergy is encouraged by the small size of the LDK community in the province; the number of the LDK Organizations through the province is so minimum that all LDK Organizations in Mataram would like to merge themselves so that they will be a bigger community.

As having taken place in other universities throughout Indonesia, the role of LDK Organization in the learning activities within the campus is also apparent. The activists of LDK Organization play their role in the assistance or the mentoring sessions for all Moslem students; this activity is known as AAI (Asistensi Agama Islam, the Assistance of Islam) is conducted prominently to the new students. The Unit of Mentoring Sessions within the structure of the LDK Organization in this campus is a semiautonomous unit and thus it is named Badan Semi Otonom Mentoring Agama Islam (SemiAutonomous Institution of Islam Mentoring). The mentors in this unit are assigned to test and guide the new students' capacity of reading Koran because reading Koran becomes the part of enrolment test. This activity is usually conducted in the beginning of the year or the beginning of the semester. In other words, all Moslem students who enrol themselves to the university should possess the capacity of reading Koran; for the Moslem students who have not possess the capacity they will be guided by the mentors of the LDK Organization. In addition to this activity, the tahsin activity to the new students will also be performed until the new students are considered to already possess the good capacity of reading Koran.

Paying attention to the guideline books of the mentoring session, it might be stated that "Tarbiyah" concept in general becomes the ideology style of the LDK Organization. This "Tarbiyah" style can be traced from the ustadz who give their lectures in the mentoring activities; these ustadz are known as the Tarbiyah Ustadz due to their slogan: "You should join Tarbiyah or you will be in trouble." As having been recorded in the website of LDK Organization, one of the ustadz is famous with that motto. The Tarbiyahstyle of Islamic preach also appears in the study of Tahqif, an acronym of Tarbiyah and Tsaqifiyah, an Islamic study that is disseminated to the mentors of Islamic preach. Despite these findings, it is interesting to add that there seems to be an effort to change the impression of the mentoring activities in the LDK Organization. The effort can be seen from the change of the name Mentoring Agama Islam (MAI, Mentoring Sessions of Islam) into Bina Pribadi Islam (Mentoring of Islamic Personality). According to a lecturer who holds the supervision on the LDK Organization, the change has been pursued in order to eliminate the "negative" impression toward the LDK activists. 
In addition, still according to the lecturer, the terms that have been associated to exclusiveness such as Ikhwan, akhwat, akhi and ukhti are replaced by brother or sister.

In addition to LDK Organization, the religious activities are also performed by PSQ. The establishment of the PSQ Organization was initialized by the lecturers of Religious Education. According to a bulletin issued by the PSQ Organization, the PSQ Organization serves to develop the students' love, interest, indulgence and study toward the knowledge of Qur'an that has been based on the governing scientific principles. In the last caretaking period, the PSQ Organization proposes the following jargon: "Being the accelerator of the Qur'an popularization among the university communities."

The activities held by the PSQ Organization is around the training programs that relate to the skill in the domain of the Qur'an reading, calligraphy art and the Qur'an study. These training programs include tilawatil Alquran, tartil Alquran, tahfid Alquran, calligraphy and papers on Alquran. Actually, these training programs are open to all students in the university but in the practice most of the participants in the training program are the members of the PSQ Organization.

In addition to holding the Alquran-related activities, the other activities that the PSQ Organization holds are related to the reading of shalawat, both the Al-Barzanzi shalawat and the other shalawat that have been read in the society. The reading of the shalawat is usually performed in the evening prior to the conduct of tilawah exercise and tartil Alquran that has been scheduled. The tradition of Shawalat reading is not found in the list of LDK Organization activities. If tilawah or tahfid can be found in both organizations then Shalawat reading can only be found in the PSQ Organization.

Another activity that the LDK Organization does not hold is writing papers on Alquran (KTI-Q, Karya Tulis Ilmiah Alquran). This activity is actually part of the efforts for internalizing the
Alquran calues through the studys that might be benefitted within the community. Indeed, the LDK Organization has a department named Division of Media which product is bulletin or wall magazine that is displayed in the mosque; however, these products are more popular and have not been based on specific study, which the activists of PSQ Organization have performed.

There are several differences that should be proposed between the two organizations. First, in terms of inter-organization member relationship it seems that the PSQ Organization is more open (inclusive) because they enable the meeting the male and female caretakers and the members of the organization to meet in the same room while the LDK Organization does not hold such a kind of meeting. Second, in terms of organizational structure it seems that the LDK Organization has clear separation between the male coordinator (Ikhwan) and the female coordinator (akhwat) while the PSQ Organization tends to not separate the male and the female coordinator. Third, in terms of shalawat reading activity the LDK Organization holds the shalawat reading activity without the use of musical instrument while the PSQ Organization holds the shalawat reading activity with the use of musical instrument. Fourth, in terms of ustadz, the ustadz who give their lectures in the LDK Organization tend to be affiliated with certain Islamic political parties or with the Salafi movement while the ustadz who give their lectures in the PSQ Organization tend to be affiliated to the Islamic boarding schools within the network of either Nahdlatul Wathan or Nahdlatul Ulama.

The four characteristics have discerned the two organizations based on the ideological affiliation. As having been frequently mentioned in the previous studys, the Tarbiyah ideology is more prominent among the activists of LDK Organization in the campus of several universities throughout Indonesia [30]-[32]. The Movement or the Pilgrims of Tarbiyah has appeared to the surface since 1980s. The appearance of the Pilgrims was inspired by the Islamic thought proposed by Hasan al-Banna (1906-1949), the founder of Ikhwanul Muslimin movement in 
Egypt [31]. Since the entrance of the movement to the public universities in Indonesia, Ikhwanul Muslimin has been developing very rapidly.

As having been found, Ikhwanul Muslimin comes to the surface as a very phenomenal movement in the Middle East region. From Egypt, the movement has gone to Syria, Sudan, Jordan, Kuwait and other Gulf countries and thus the movement has formed the main Pan-Islamic Arab. The recruitment of the group relies on the cell system, which enables the rapid development. Halaqah and daurah are held in houses, mosques, campuses and both the open and close platforms. These activities are known as usrah (group/family). Each group consists of 10 to 20 members under the leadership of a murabbi (instructor/mentor). It is this activity that inspires the mentoring activities within the scope of LDK Organization on several universities [33].

Ikhwanul Muslimin develops Islamic preach or dakwah as the framework for their struggle. Hasan al-Banna, through his slogan "Islam is constitution," asserts that Islam is a complete and all-encompassing system. Every single thing has been clearly explained in Koran, which moral principles are believed to be universal. Then, the development of Ikhwanul Muslimin becomes more rapid with the appearance of Sayyid Qut who later becomes the great ideologist for the movement. He wrote a book entitled Ma'alim fi al-Tariq which will be the classical reference for the Islamists throughout the world. The book also asserts the presence of Jahiliyah Age or the Age of Darkness as the result of abandoning Syariah. For Qutb, Moslem people have gained their success in turning the direction in the history and taking over the power from the West by following the role model of salaf al-saleh. Qutb described these people as the outstanding group of Qur'ani generation who stayed consistent in the path of dakwah by standing on the ground of their belief toward tauhid [33]. In sum, the ideology of Tarbiyah emphasizes the doctrine of committing kaafah (all-encompassing) literally in internalizing the Islamic teachings throughout all life aspects including the state affairs (Ali, 2012, p. 73). Despite the ideology, the excess of the ideology is the appearance of other factions that tend to be more radical in comparison to Ikhwanul Muslimin.

In general, there are two paths of Ikhwanul Muslimin movement in Indonesia. The first path is the path of Tarbiyah/Pilgrims. This path concentrates on the preparation of the cadres on the grassroot level who will be the base of the most solid mass. In preparing this cadre, Tarbiyah/Pilgrims should rely on halaqah. The Islamic prayer materials that have been developed in halaqah are, for example, guidelines for the development of Islam cadres and the management of tarbiyah activities. These materials are designed in a guidebook named Manhaj Tarbiyah Islamiyah. Then, the second path is the path of Siyasah/Party. Siyasah/Party serves as the actualization for the Islamic cadres in the domain of politics. The ideas that have been developed in the path of Tarbiyah are interpreted into the field of political party. Therefore, political party is considered as the extension of dakwah strategy. In addition to the two main paths, there are other paths that might be benefitted. For example, the path of tarbiyah amaliah is related to the business activities. There are also other paths of Tarbiyah that have been developed in the domain of professional workers by means of small group formation; these tarbiyah groups are usually found in both the public offices and the private offices. The activities of these tarbiyah groups are usually around the religion affairs held by the caretakers of the mosque in these offices. In addition to the tarbiyah movement in the domain of professional workers, there are also tarbiyah movements in the domain of military known as tarbiyah askariyah/paramilitary; these movements are known as paramilitary groups. This path is the military wing within the Pilgrims environment. The simplest form for the paramilitary path is liqa (meeting) which involves the cadres to join physical and martial art exercises [34].

Referring to several paths of the activities or the movement, the activities of the LDK Organization are usually manipulated as the part of the path of Tarbiyah/ Pilgrims. Since the movement has been brought about from other country/nation, it might 
be stated that Tarbiyah movement is a transnational-exclusive movement. Based on the findings in the study, the term exclusive is pinned due to the fact that the Tarbiyah movement displays religious attitudes and social relationship that tend to be closed. In an interview, an exactivist from the LDK Organization told how the strong is the regulation that she should abide to.

At that time, I did not have any motorcycle.Consequently, everytime we have an activity I should take a free ride with my friends who have one. It was a coincidence that all of my friends who have motorcycle are male. So, finally I went along with them but my seniors there prohibit me to not take a free ride with the male student who was not my muhrim (spouse). It was better for me to leave the LDK Organization.

Although I have resigned from the LDK Organization, my seniors in the institution always contact and ask me to return again (12/3/2018).

Indeed, not all students who join the activities held by the LDK Organization are aware of the map and the ideology of the movement; however, paying attention to the results of the interview with the senior members of the LDK Organization it is apparent that these senior members adopt certain ideology. in addition, the ideology style that has been adopted is apparent in a number of texts that they refer in the holding several activities or studys.

Different than the LDK Organization that tends to have Tarbiyah/Ikhwan-style Ideology, the PSQ Organizations are more open. Based on the observation and the interview that have been conducted, it might be concluded that the activists of the PSQ Organization have more "traditional" characters although they are more open (inclusive) especially in terms of both the inter-member relationship and the study of religion that has been proposed.

The meaning of the term "inclusivetraditionalism" that has been pinned to the PSQ Organization here is that the activists of this organization display more obedience to a teacher, tuan guru or kyai, based on the doctrine sami'na wa ata'na (we listen and we obey) on the one hand but on the other hand they are more open to the social relationship and even to the ideas outside the ones that the activists of this organization believe. In addition, such traditionalistic attitude is reflected in numerous rituals that the members of the organization perform just as the other activists of Nahdlatul Ulama (NU) and Nahdlatul Wathan (NW) perform such as tahlil and salawatan. Indeed, most of the PSQ activists are more affiliated to the two organizations. However, the PSQ Organization is more open to any university student who wants to join their activity despite the background; even some of the female activists are dressing in veils (niqab).

The inclination of the PSQ Organization to be affiliated to the two organizations are apparent from the activities that they hold. The activities of the PSQ Organization, such as study or workshop, are frequently held in the Islamic boarding schools that at certain level are affiliated to the organizations. According to several scholars, such as van Bruinessen, NU is a traditionalistic Islamic group but the progressivity of their paradigm is equal to the modernistic Islamic group [35]. The characteristics of the traditionalism that NU has are apparent in several rituals such as tahlili, selametan and communal reading of salawat, which to the modernistic Islamic group is considered as heresy. These rituals are also practiced by the activists of PSQ.

Similar situations also occur in the NW Organization, who is considered to have traditionalistic view as well. In addition to practicing tahlil, selametan and salawat reading, NW forms their identity by regularly reading wirid and hizib of Nahdlatul Wathan [7]. Furthermore, both NW and NU strengthen their obedience toward the teacher or known as guru or kyai. Despite the similarities, the characteristic that differentiate NW from NU is found in the address of Syafii school of thought. NW declares that they only belong to the Syafii school of thought in their Articles of Association/Bylaws 
[36] while NU declares that they belong to four schools of thought in Fikih.

Both NU and NW have similar political orientation in their ideology. NU proposes the moderate orientation or the middle way in the domain of politics; in other words, NU can be considered to have accommodative orientation in the domain of politics [37]. On the other hand, the Tarbiyah movement defends Islam more as the state ideology. This attitude then puts the Tarbiyah movement vis a vis to the state. All life aspects that are not based on the Islamic teachings should be considered illegal.

The above explanation shows that both universitystudent organizations seems to normally operate in the domain of religion but in the practice they have different ideology and point of view. The different ideology and point of view then gives peculiar style to the practice of literacy and the selection of literatures between the two organizations.

\section{The Literacy Practices}

The two different ideologies separate the practice of literacy in each religious group (LDK and PSQ) of the university; despite the differences, both groups still share several similarities. Before discussing the different aspects, the similar aspects between the two religious groups will be proposed in the first place. Both organizations have the figures that will determine the fate of the organizations. The statement implies that both organizations have some kind of patron-client relationship. Despite the similarity, there is a single difference that can be found in the figures who become the role models of each organization. In other words, the practice of literacy still centres on certain figure with more "listening" culture than "discussing" culture and even with very few "interpreting" culture. In addition, the "listening" culture is influenced by the style or the orientation of each role model in both organizations.

Looking at the patron-client relationship in both organizations, it is apparent that the practice of literacy is a practice that has been sponsored by borrowing the words of Brandt - certain figures whose implications can be found in the selection of literatures (reading and writing) in both organizations. Since the sponsor of the practice of literacy is the figures with the characteristics of certain religious ideology, the practice of literacy between the two organizations is also conducted in accordance to the "sponsor's order" implied by the figures. This explanation might be described through the following figure. 


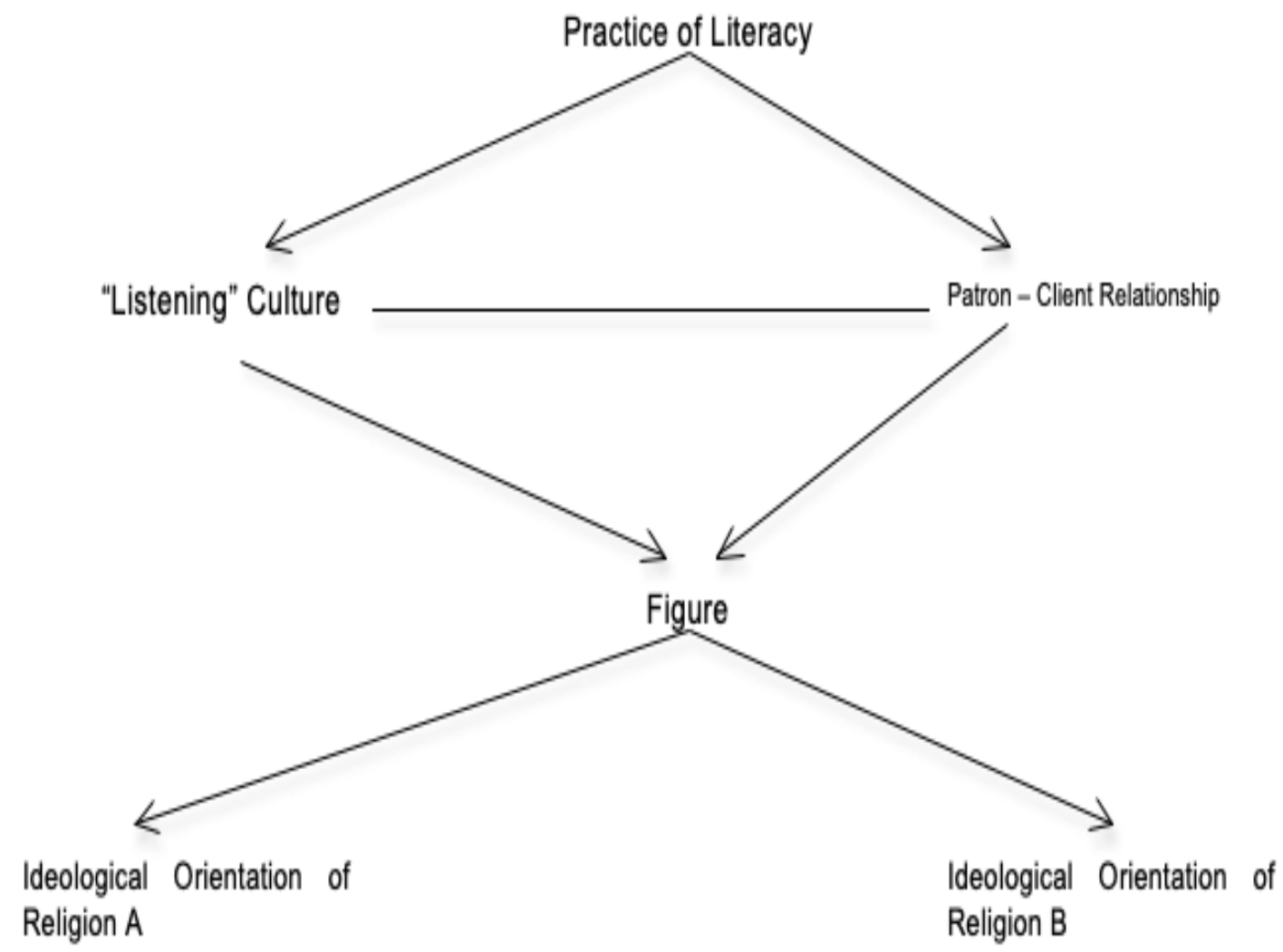

Figure 1. Scheme on the Relationship between the Practice of Literacy with Central Figures and the Ideological Orientation

As having been explained previously, there are differences between the LDK Organization and the PSQ Organization. Indeed, both organizations internalize the "listening" culture but the PSQ Organization a practice of literacy that emphasizes the "interpreting" culture more. Despite the fact that the productive of such literacy practice is far from the expected quality, at least there are efforts to develop the "interpreting" culture. The "interpreting" culture is manifested into composing scientific papers about Koran. Based on the titles that have been successfully documented, these scientific papers are interesting to observe as part of actualization on religious concepts among the university students. These titles are related to the topics of Koran and Science and Technology, Koran and Society and also Koran and Education. The examples of these titles are as follows: "The Effect of Heart Work Abnormality due to Uncontrolled Negative Emotions (Anger) in the Perspective of Koran and Science," A Study toward Tears Therapy and Its Influence to Heart Work in the Perspective of
Koran" and "The Perspective of Islamic Law on the Religious Tolerance in Indonesia."

The "interpreting" culture in the practice of literacy is a characteristic of the active or productive literacy. The "interpreting" culture that is manifested into the form of papers refers to the stage of literacy creation that the university students have achieved in solving the problems that they encounter based on the Koran study that they have conducted. The culture is very apparent from the titles of the scientific papers themselves, which can be considered as a combination between "passive literacy" and "active literacy." Passive literacy emphasizes the skills of absorbing information and knowledge more, while active literacy emphasizes the skills of creating information and knowledge. This conception is borrowed from the concept of media and information literacy.

Media and information literacy refer to the competencies that display the capacity of an 
individual in accessing, evaluating, using and creating media in numerous forms critically and ethically [38]. If accessing, evaluating and using are part of passive literacy then creating is part of active literacy. Therefore, it can be concluded that scientific papers are the actualization of active literacy among the university students who become the members of PSQ Organization; since these papers are parts of active literacy, the "listening" culture tends to shift a little bit to the "interpreting" culture in the practice of Islam literacy.

The conception of the culture of listening and the culture of interpretation in the practice of religious literacy dates back to the results of a study by Rackley [39] on the practice of literacy by two different religious communities namely Methodist and Latter-Day Saint. The Methodist Community develops the interpreting culture by actively constructing the meanings from the Bible or the other religious texts.

The activities of the Methodist Community are mostly discussions and presentations. On the other hand, the Latter-Day Saint Community develops the listening culture more by passively accepting the meanings from the Bible or the other religious texts. Based on the description, it is apparent that the activities that both communities have performed are reading Bible memorizing Bible and internalizing belief that Bible is the actualization of their faith.

This Rackley study might be developed in line with the findings in the present study. The listening culture is indeed practiced by both the LDK Organization and the PSQ Organization. The listening culture does not imply that both organizations do not read any religious texts. The members of both organizations indeed read the religious texts but these texts are accepted and understood passively without any effort to construct the meaning that these texts carry. Therefore, in order to strengthen the conception of listening culture that Rackley has proposed the present study will use the term "passive literacy" in the practice of religion literacy. The reason is that in the reality both organizations do not only "listen" but also "read" the religious texts although they read these texts with passive attitude.

The culture of interpretation - in Rackley conception - has been practiced by the PSQ Organization in line with the practice of listening culture. This culture of interpretation is less appearent in the religious literacy practice of LDK community. As a result, the practice of literacy and the interpreting culture is still practiced altogether with the listening culture. The more interesting fact is that the interpreting culture is practiced by the PSQ Organization, which is ideologically more traditional-oriented (NU and NW).

The elements that differentiate the PSQ Organization and LDK Organization certainly centre on the patron or the sponsor behind the organizations' practice of literacy. The patron of literacy refers to the role model and the figure of the practice of literacy in a community. Thereby, the practice of literacy in both organizations will heavily depend on the patron of literacy who becomes their role model. The listening culture and the interpreting culture are only the extension of the role that the patron of literacy plays. The role that the patron of literacy plays is also influenced by the ideological orientation of the figure who becomes the role model. 


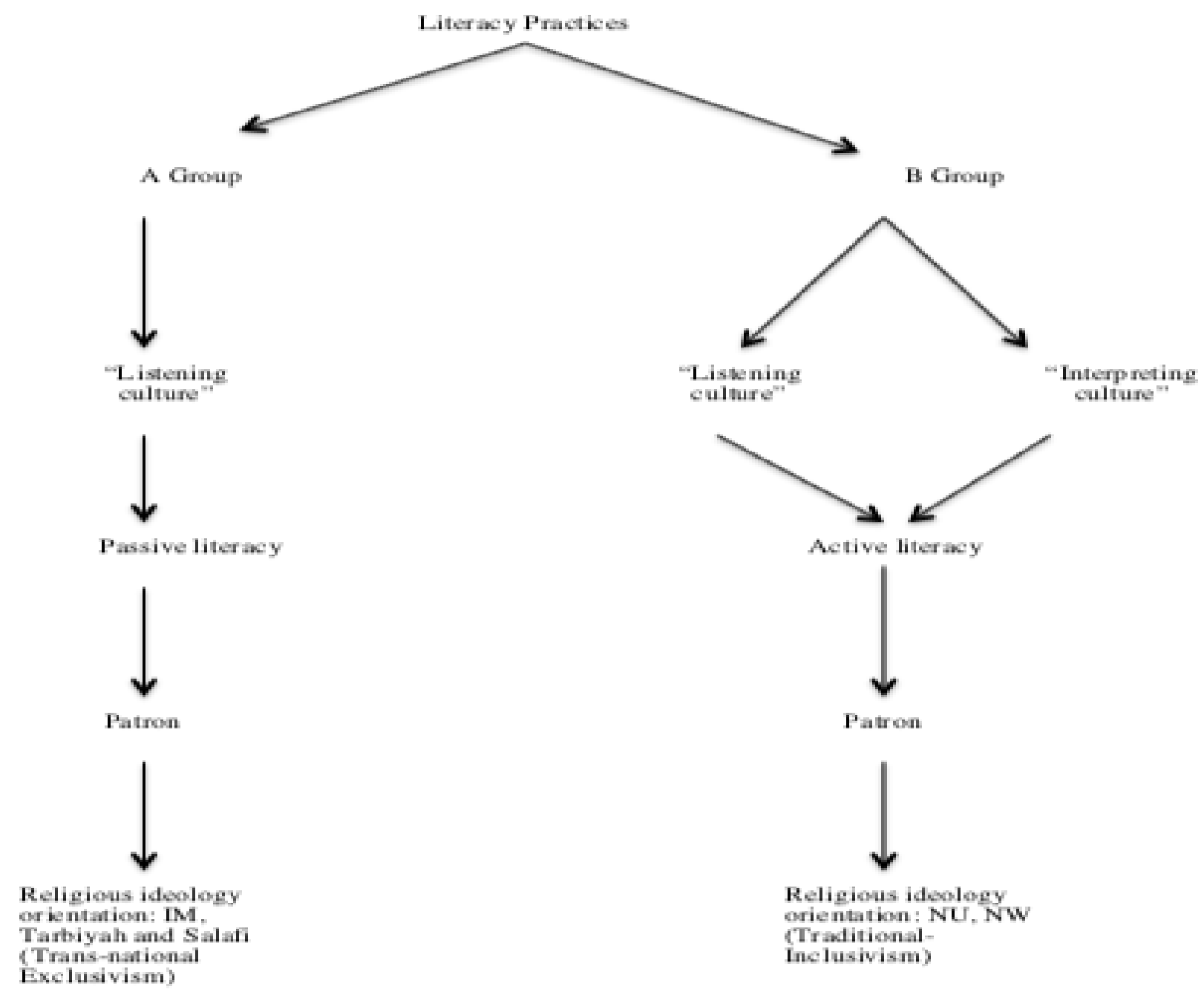

Figure 2. Scheme on the Relationship among the Listening Culture, the Interpreting Culture, the Patron's Role and the Ideological Orientation in the Practice of Islamis Religious Literacy.

The strong patron's role might be associated to the tradition of Islamic education that have been developing both in Middle East and in Indonesia. It is the patron's role that enables the relationship between the ideology and the practice of literacy. As having been disclosed, most of the times the ustadz who have been invited into the practice of Islam literacy activities display obvious polarization. The ustadz from Tarbiyah movement frequently appear in the slogans by the LDK Organization activists. On the contrary, the ustadz from the traditions of Islamic boarding schools are frequently engaged in the activities held by the PSQ Organization. This matter is interesting since there is a fact that the patron is not always part of the intervention by the university that fosters the two organizations. As having been found, the affiliation of the LDK Organization coaches are the NW Organization; however, in the practice many ustadz who have been involved in the activities held by the LDK Organization are from the Tarbiyah movement. In comparison, the affiliation of the PSQ Organization coaches are from the traditionalist movement and thus the ustadz who have been engaged in their activities are from the traditionalist movement.

\section{Conclusion}

By using the ideological and contextual perspective, the present study proposes that the practice of Islam literacy among the religious communities has relationship to the ideology. The ideology itself is also related to the patron in each 
organization. The practice of literacy pattern in both organizations under the study have certain characteristics which lead to the association to the basis of religious ideology that has been adopted by the patron and the activists from the two organizations.

The present study has found that the LDK Organization pays more attention to the listening culture in the practice of literacy; as a result, the LDK Organization displays the passive literacy. On the contrary, the present study has also found that the PSQ Organization pays the listening culture in addition to the interpreting culture; the evidence of such practice can be traced to the existence of scientific papers on Koran the members of PSQ Organization have composed and thus it might be concluded that the PSQ Organization displays the active literacy. In sum, this case can be traced back to the ideological base that the two organizations have adopted. The LDK Organization adopts the exclusive-transnational ideology while the PSQ Organization adopts the inclusive-traditional ideology.

\section{References}

[1] F. Ghufron, "Menumbuhkan Literasi Agama," Kompas, Jakarta, p. 6, 12-Apr2017.

[2] S. Dewayani and P. Retnaningdyah, Suara dari Marjin: Literasi sebagai Praktik Sosial. Bandung: PT. Remaja Rosda Karya, (2017).

[3] D. Brandt, Literacy in American Lives. Cambridge: Cambridge University Press, (2001).

[4] C. Lankshear and M. Knobel, "Education and 'new literacies' in the middle years," Literacy Learning in Middle Years, vol. 26, no. 2, pp. 7-17, (2018).

[5] J. E. Oghenekohwo and E. A. Frank-Oputu, "Literacy Education and Sustainable Development in Developing Societies," International Journal of Educational Literacy Studies, vol. 5, no. 2, pp. 126-131, (2017).

[6] K. Pahl and J. Rowsell, Literacy and Education: Understanding the New
Literacy Studies in the Classroom. London: Paul Chapman Publishing, (2005).

[7] Saparudin, Ideologi Keagamaan dalam Pendidikan: Diseminasi dan Kontestasi pada Madrasah dan Sekolah Islam di Lombok. Tangerang Selatan: Onglam Books, (2017).

[8] S. Saparudin, "Salafism, State Recognition and Local Tension: New Trends in Islamic Education in Lombok," Ulumuna, vol. 21, no. 1, pp. 81-107, (2017).

[9] O. Safi, The Politics of Knowledge in Premodern Islam: Negotiating Ideology and Religious Inquiry. North Carolina: The University of Carolina Press, (2006).

[10] E. D. Rackley, "Scripture-based discourses of Latter-day Saint and Methodist youths," Read. Res. Q., vol. 49, no. 4, pp. 417-435, (2014).

[11] S. H. Jones, "Religious Literacy in Higher Education," in Religious Literacy in Policy and Practice, A. Dinham and M. Francis, Eds. Bristol and Chicago: Policy Press, pp. 187-206, (2005).

[12] H. Latief, "Youth, Mosque and Islamic Activism: Islamic Sources Books in University-Based Halaqah," Kult. Indones. J. Muslim Cult., vol. 5, no. 1, pp. 63-88, (2010).

[13] A. Akbar, "Berjuang di Jalan Dakwah: Kajian Pemetaan Buku-buku Keagamaan di Universitas Negeri Yogyakarta," J. Lekt. Keagamaan, vol. 5, no. 1, pp. 85-104, (2007).

[14] A. Saefullah, "Peta Lektur Keagamaan pada Kelompok Keagamaan di IPB: Benang Merah Gerakan Islam Asasi," J. Lekt. Keagamaan, vol. 6, no. 1, (2008).

[15] M. Nur, "Bahan Bacaan Aktivis Kampus di Universitas Padjajaran (UNPAD) Bandung," J. Penamas, vol. 29, no. 2, pp. 265-278, (2016).

[16]Z. Yani, "Bacaan Keagamaan Aktivis Keagamaan di Universitas Pendidikan Indonesia (UPI) Bandung," J. Penamas, vol. 29, no. 1, pp. 67-80, (2016).

[17] A. Iswanto, "Ideologi dalam Literatur Keagamaan pada Aktivis Dakwah Kampus dan Kajian Islam di ITB Bandung," $J$. 
SMaRT Stud. Masyarakat, Reli. dan Tradisi, vol. 03, no. 01, pp. 13-27, (2017).

[18] B. V Street, "Introduction," in Literacy and Development: Ethnographic Perspective, B. V Street, Ed. New York: Routledge, pp. 21-26, (2001).

[19] T. Eagleton, Introduction to ideology. London and New York: Verso, (2015).

[20] C. Tan, Islamic education and indoctrination:The case in Indonesia. New York: Routledge, (2011).

[21] R. D. Lee, Religion and Politics in the Middle East: Identity, Ideology, Institution, and Attitutedes. Colorado: Westview Press, (2014).

[22] H. M. Federspiel, Islam and Ideology in the Emerging Indonesian State: The Persatuan Islam (PERSIS), 1923 to 1957. Leiden: Brill, (2001).

[23] J. C. Liow, "Muslim Identity, Local Networks, and Transnational Islam in Thailand's Southern Border Provinces," Mod. Asian Stud., vol. 45, no. 6, pp. 13831421, (2011).

[24] R. W. Hefner, "Islamic Schools, Social Movements, and Democracy in Indonesia," in Making Modern Muslims: The Politics of Education in Southeast Asia, R. W. Hefner, Ed. Honolulu: University of Hawai'i Press, pp. 55-105, (2009).

[25] K. Bryner, "Piety Projects: Islamic Schools for Indonesia's Urban Middle Class," Columbia University, (2013).

[26] N. Hasan, "Education, Young Islamists and Integrated Islamic Schools in Indonesia," Stud. Islam., vol. 19, no. 1, pp. 77-111, (2012).

[27] Zulkifli, "Education, identity, and recognition: E Shi'i Islamic education in Indonesia," Stud. Islam., vol. 21, no. 1, pp. 77-108, (2014).

[28] A. Rosowky, "Faith Literacies," in The Routledge Handbook of Literacy Studies, J. Rowsell and K. Pahl, Eds. London and New York: Routledge Taylor and Francis Group, pp. 169-180, (2015).

[29] Rof'ah and N. Mariani, "Reception and Negotiation: Literatur Keislaman di Kota Mataram," (2017).
[30] B. Muhtadi, "Thinking Globally, Acting Locally: A Social Movement Theory Approach of the Prosperous Justice Party (PKS) and Its Islamist Transnational Framing," The Australian National University, (2008).

[31] Y. Machmudi, Islamising Indonesian: The Rise of Jemaah Tarbiyah and the Prosperous Justice Party (PKS). Canberra: ANU E Press,(2008).

[32] Salman, "The Tarbiyah Movement: Why People Join This Indonesian Contemporary Islamic Movement," Stud. Islam., vol. 13, no. 2, (2006).

[33] N. Hasan, Islam Politik di Dunia Kontemporer: Konsep, Geneologi dan Teori. Yogyakarta: Suka Press, (2012).

[34] A. S. Ali, Ideologi Gerakan PascaReformasi: Gerakan-gerakan SosialPolitik dalam Tinjauan Ideologis. Jakarta: LP3ES, (2012).

[35] M. van Bruinessen, NU: Tradisi, Relasirelasi Kuasa, Pencarian Wacana Baru. Yogyakarta: LKiS, (1999).

[36] F. Ismail, Islamic Traditionalism in Indonesia: A Study of the Nahdlatul Ulama's Early History and Religious Ideoloy. Jakarta: Puslitbang Kehidupan Beragama, Badan Litbang dan Diklat Kementerian Agama, (2003).

[37] A. Feillard, NU vis-à-vis Negara: Pencarian Isi, Bentuk dan Makna. Yogyakarta: LKiS, (2008).

[38] UNESCO, Global Media and Information Literacy Assessment Framework: Country Readiness and Competencies. Paris: UNESCO, (2013).

[39] E. D. Rackley, "Motivation for Religious Literacy Practices of Religious Youth: Eximining the Practices of Letter day Saint and Methodist Youth in One Community," Michigan University,(2010). 